\title{
Localization of plasminogen activator inhibitor type 1 and 2 in preimplantation mouse development in vitro
}

\author{
Duygu MUTLUAY ${ }^{1,2, a, ®}$, Yukiko YAMAZAKI ${ }^{2, b}$, Kanani HOKUTAN ${ }^{3,4,5, c}$, Charles J ROSSER ${ }^{3,4,5,6, d}$, \\ Hideki FURUYA ${ }^{3,4,5,6, e}$
}

\begin{abstract}
${ }^{1}$ Mehmet Akif Ersoy University, Faculty of Veterinary Medicine, Department of Histology and Embryology, Burdur, Turkey; ${ }^{2}$ University of Hawaii, John A. Burns School of Medicine, Institute of Biogenesis Research; ${ }^{3}$ University of Hawaii, Cancer Center, Clinical and Translational Research Program; ${ }^{4}$ University of Hawaii Cancer Center, Cancer Biology Program; ${ }^{5}$ University of Hawaii, Department of Molecular Biosciences and Bioengineering, Honolulu, Hawaii; ${ }^{6}$ Department of Surgery, Division of Urology, CedarsSinai Medical Center, Los Angeles, California, USA aORCID: 0000-0003-3286-130X; b ORCID: 0000-0001-5089-1487; ' $O R C I D: 0000-0003-1494-2392$; ${ }^{\mathrm{d}}$ ORCID: 0000-0002-6052-4223; ${ }^{\mathrm{e} O R C I D: 0000-0002-9536-8662 .}$
\end{abstract}

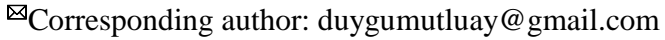 \\ Received date: 28.02.2019- Accepted date: 29.05.2019
}

\begin{abstract}
Plasminogen activator inhibitor type 1 (PAI-1) and type 2 (PAI-2) are the major endogenous inhibitors of fibrinolysis, or thrombolysis, as it is effective in blocking the conversion of plasminogen to plasmin. In mammalian embryos, both PAI-1 and PAI2 proteins are expressed in the trophoblasts during and after implantation, suggesting their critical roles in implantation and placentation during pregnancy. However, it remains unclear how both proteins localize in the early stage embryos before implantation. In this study, 2 cell stage embryos were flushed from the oviducts and cultured to specified stages in medium at $37^{\circ} \mathrm{C}$ in a $5 \% \mathrm{CO}_{2}$ incubator. Embryos were fixed and double immunostained with anti-PAI-1 and anti- PAI- 2 antibody. We determined the critical expression and localization patterns of PAI-1 and PAI-2 proteins in murine preimplantation embryos at 2 cell, 8 cell, morula and blastocyst stages by using confocal laser scanning microscope. We found that PAI-1 and PAI-2 constantly express in the embryos during preimplantation development, and these proteins localize in both the cytoplasm and the nucleus of each blastomere regardless of their developmental stage. Our results suggest that PAI-1 and PAI-2 proteins may play roles in early embryonic development before implantation.
\end{abstract}

Keywords: Embryo development, PAI-1, PAI-2, preimplantation.

\section{Farelerde preimplantasyon embriyo gelişiminde plazminojen aktivatör inhibitör tip 1 ve 2'nin in vitro lokalizasyonu}

Özet: Plazminojen aktivatör inhibitör tip 1 (PAI-1) ve tip 2 (PAI-2), plazminojenin plazmaya dönüşümünü bloke etmede etkili olduğundan fibrinolizis veya trombolizisin başlıca endojen inhibitörleridir. Memeli embriyosunda, hem PAI-1 hem de PAI-2 proteinlerinin implantasyon sırasında ve sonrasında trofoblastlarda eksprese ediliyor olması gebelikte bu proteinlerin implantasyon ve plasentasyonda kritik rolleri olduğunu düşündürmektedir. Bununla birlikte, her iki proteinin implantasyondan önce erken embriyo döneminde nasıl lokalize olduğu konusu hala açık değildir. Bu çalışmada, 2 hücre evrede bulunan embriyolar oviduktlar yıkanılarak çıkarıldı ve $\% 5^{\prime}$ lik $\mathrm{CO}_{2}$ inkübatöründe $37^{\circ} \mathrm{C}$ 'de belirtilen aşamalara göre kültüre edildi. Embriyolar tespit edildi ve anti-PAI-1 ve antiPAI-2 antikoru kullanılarak ikili immunboyama yapıldı. PAI-1 ve PAI-2 proteinlerinin murin preimplantasyon dönemi embriyolarındaki kritik ekspresyon ve lokalizasyon paternleri 2 hücre, 8 hücre, morula ve blastosist aşamalarında konfokal lazer tarama mikroskobu kullanarak belirlenmiştir. PAI-1 ve PAI-2'nin preimplantasyon gelişimi sırasında embriyolarda sürekli eksprese ettiğini ve bu proteinlerin gelişim aşamalarına bakılmaksızın her bir blastomerin hem çekirdeğinde hem de sitoplazmasında lokalize olduğu gösterilmiştir. Bu sonuçlar, PAI-1 ve PAI-2 proteinlerinin implantasyon öncesinde erken embriyo gelişimde rol oynuyor olabileceğini göstermektedir.

Anahtar sözcükler: Embriyo gelişimi, PAI-1, PAI-2, preimplantasyon.

\section{Introduction}

Plasminogen activators (PAs) are serine proteases that catalyze the activation of plasmin, which is a factor to breakdown fibrin polymers during blood clotting (22).
Two mammalian PA isoforms, tissue plasminogen activator (tPA) and urokinase-type plasminogen activator (uPA) are the central components of the plasmin/plasminogen activator system, which plays a 
major role in benign disorders such as deep vein thrombosis, myocardial infarction, atherosclerosis, and stroke (9). Plasminogen activator inhibitor-1 and -2 (PAI1 and PAI-2) are known to be the major inhibitors of this system $(7,29)$. PAI-1 expression is regulated by a number of intrinsic factors (e.g., cytokines and growth factors) and extrinsic factors (e.g., cellular stress) (29). In the early stage embryos, PAI-1 is expressed in trophoblasts, cytotrophoblasts, trophectodermal cells $(5,24)$ endothelial cells and placental cells (30). PAI-2 is also present in placental trophoblasts and macrophages and keratinocyte $(2,8)$. During the second trimester of pregnancy in humans, the concentration of PAI-1 in mother's plasma is gradually increased and it reaches a peak at 32-40 weeks of pregnancy (14). The PAI-2 concentration is also increased during pregnancy and birth (2).

Accumulating evidence suggests that PAs are implicated in oocyte meiotic maturation (16), ovulation (21), fertilization $(17,34)$ and embryo implantation (31). In rat embryos, uPA and tPA are expressed throughout their preimplantation development. While uPA is localized in the cell cytoplasm, tPA is detected only on cell surface and in the perivitelline space (1). In light of these studies, we hypothesize that the expression of PAI-1 and PAI-2 may be also important to maintain the normal embryogenesis. However, the critical expression patterns of PAI-1 and 2 in mammalian preimplantation embryos remain, unclear. In this study for the first time we obtained critical information about the localization of PAI- 1 and 2 proteins throughout the embryo development in vitro by using immunofluorescence confocal microscopy.

\section{Material and Methods}

Animals and collection of embryos: C57BL/6J (Jackson Laboratory, Bar Harbor, ME) female and male mice were used in this study. Females at 6-8 weeks old were mated with males at 12-16 weeks old. After the mating, females with the vaginal plug were indicated as Day 1 of pregnancy. On Day 2 of pregnancy, females were sacrificed to dissociate their oviducts. Two-cell stage embryos were flushed out from the oviducts in M2 medium (MR-015P, Sigma-Aldrich). These 2-cell embryos were cultured in $20 \mu \mathrm{l}$ drops of KSOM-AA medium (MR-121, Millipore) overlaid with mineral oil at $37^{\circ} \mathrm{C}$ in $5 \% \mathrm{CO}_{2}$ in air for up to Day 5 (26). The embryos at 2-cell (Day 2), 8-cell (Day 3), morula (Day 4) and blastocyst (Day 5) stages were subjected to immunoflorescent staining. At least three pregnant females were used to collect each stage embryos. All relevant experimental procedures were reviewed and approved by the Institutional Animal Care and Use Committee of the University of Hawaii with a Protocol No. 11-1160-8.
Double immunofluorescent staining: The embryos at different stages were fixed for $15 \mathrm{~min}$ at room temperature. After fixation, the embryos were permeabilized for $15 \mathrm{~min}$ and blocked with $5 \%$ bovine serum albumin. Then the embryos were incubated in the primary antibodies overnight at $4^{\circ} \mathrm{C}$ The primary antibodies provided were rabbit polyclonal anti-PAI-1 (1:400 dilution; sc-8979, Santa Cruz) and goat polyclonal anti-PAI-2 (1:400 dilution; sc-6649, Santa Cruz). After the first antibodies treatment, the embryos were incubated with secondary antibodies for $2-3 \mathrm{~h}$ at room temperature. The secondary antibodies were conjugated with DyLight 488 (1:500; Thermo Fisher Scientific, Life Technologies), namely donkey anti-goat and Alexa Fluor 568 (1:500; Life Technologies), namely, goat anti-rabbit for $3 \mathrm{~h}$ at $25^{\circ} \mathrm{C}$. Stained samples were mounted in ProLong Gold antifade reagent containing $\quad 4^{\prime}, 6^{\prime}$-diamidino-2-phenylindole (DAPI) (Life Technologies) on a slide (25). Negative and positive control staining on embryos were done during this study. The negative control groups underwent the same staining protocol as the positive control group with the absence of the primary antibody. Moreover, the specificity of the PAI-1 and 2 secondary antibody was determined that no PAI-1 and 2 staining was observed in negative control groups.

Microscopy and image analysis: Embryos were imaged using a Leica TCS SP5 confocal laser scanning microscope. For confocal microscopy, serial optical sections were imaged at 1-2 $\mu \mathrm{m}$ intervals under a $60 \mathrm{x}$ objective lens with oil.

\section{Results}

Localization of PAI-1 and 2 proteins during the mouse preimplantation development: To determine the expression patterns of PAI-1 and 2, proteins during preimplantation development, mouse embryos from 2-cell to blastocyst stages were double immunostained with antiPAI-1 and 2 antibodies. In the 2-cell stage embryos ( $\mathrm{n}=$ 25), both PAI-1 (red) and PAI-2 (green) proteins localized in the cytoplasm and the nucleus (Figure 1). In addition, polar bodies in the 2-cell embryos showed PAI-1 and 2, staining positive (Figure 1), suggesting that PAI-1 and 2 proteins are produced not only in the embryo after fertilization, but also in the female-specific oocytes. In the advanced embryos at the 8 -cell $(\mathrm{n}=10)$ and the morula $(\mathrm{n}=$ 25) stages, PAI-1 and 2, expressions were constantly observed (Figure 2). These proteins were entirely observed in the cytoplasm and the nucleus except a few nucleoli (Figure 2). In morula stage embryos (16-32 cells) strongly stained dotty structures were observed in each blastomeres regardless of their internal or external position (Figure 2). 

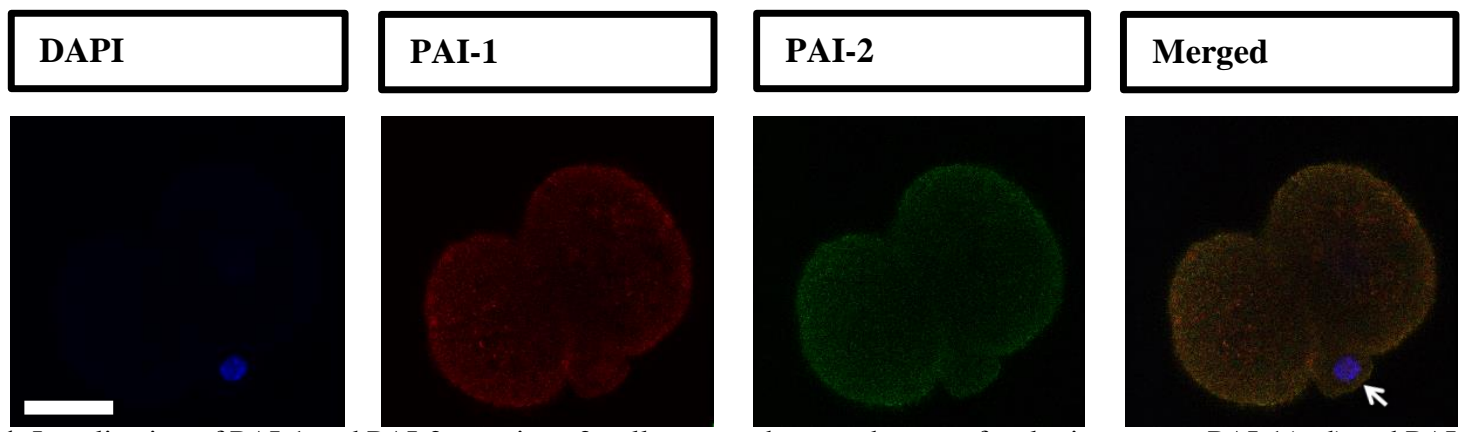

Figure 1. Localization of PAI-1 and PAI-2 protein at 2-cell stage embryo under a confocal microscopy. PAI-1(red) and PAI-2 (green) were localized in the polar body (arrow). Nuclei were stained with DAPI (blue). Scale bar represents $20 \mu \mathrm{m}$. DAPI: 4',6'- Diamidino2-phenylindole, PAI-1: Plasminogen Activator Inhibitor Type 1, PAI-2: Plasminogen Activator Inhibitor Type 2.
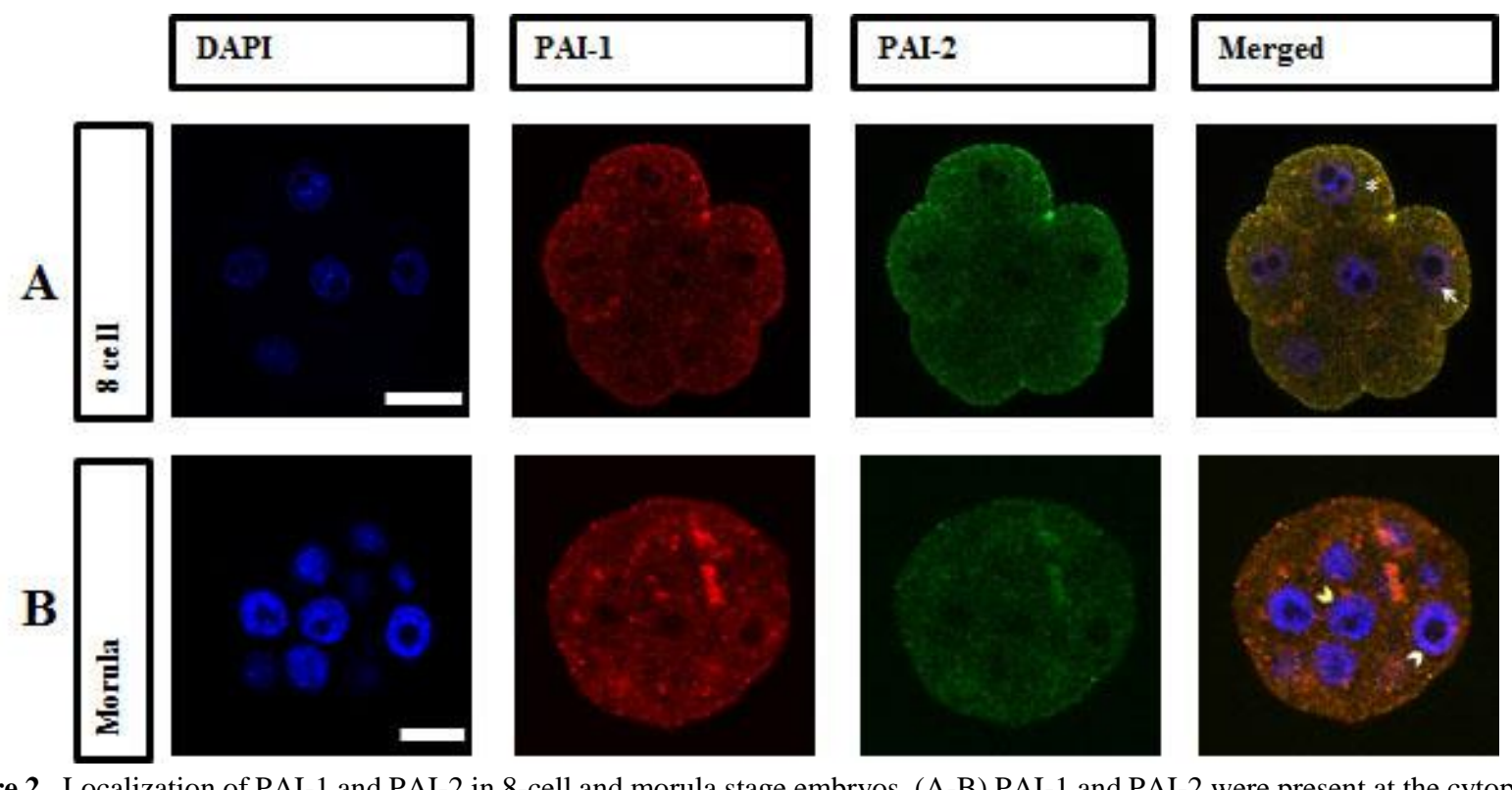

Figure 2. Localization of PAI-1 and PAI-2 in 8-cell and morula stage embryos. (A-B) PAI-1 and PAI-2 were present at the cytoplasm (asterisk) and nucleus (arrow). External (white arrowhead) and internal cells (yellow arrowhead) cytoplasm and nuclei were positively stained with PAI-1 and PAI-2. Confocal optical sections of embryos immunofluorescently stained with PAI-1 (red), PAI-2 (green) and nuclei stained with DAPI (blue). Scale bar represents $20 \mu \mathrm{m}$.
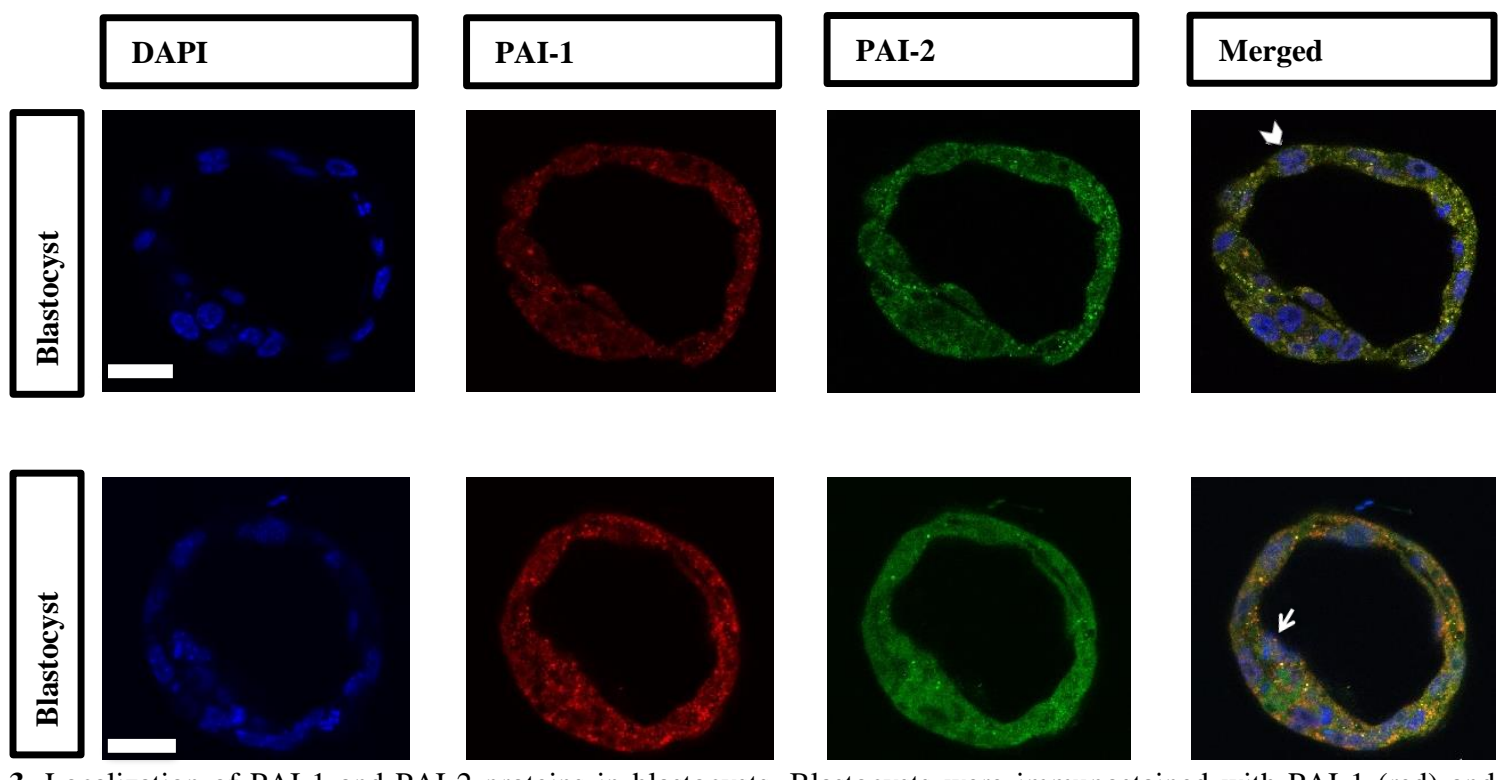

Figure 3. Localization of PAI-1 and PAI-2 proteins in blastocysts. Blastocysts were immunostained with PAI-1 (red) and PAI-2 (green). The nuclear and cytoplasmic staining on TE cells (arrowhead) and on ICM (arrow). Nuclei were stained with DAPI (blue). Scale bar represents $20 \mu \mathrm{m}$. 
At the blastocyst stage, the embryos differentiate into two different cell lineages, trophectoderm (TE) and inner cell mass (ICM). After the double immunostaining of the blastocyst embryos, the blastomeres in TE and ICM were strongly stained with both PAI-1 and PAI-2 antibodies (Figure 3). Both proteins were localized in the cytoplasm and the nucleus (except a few nucleoli) in each blastomere at the blastocyst stage. In conclusion, PAI-1 and PAI-2 were detected in the early mouse embryos in all preimplantation stages, suggesting that PAI-1 and 2 proteins are constantly expressed in the early stage embryos before implantation in the mother's uterus.

\section{Discussion and Conclusion}

In the present study, we demonstrated that PAI-1 and 2 are constantly expressed and localized in both the cytoplasm and the nucleus in the mouse embryos throughout the preimplantation period. Our results indicate that PAI-1 and PAI-2 may contribute to normal preimplantation development essential for successful implantation and maintaining the pregnancy.

Previous studies reported that PAI-1 and 2 are expressed in human trophoblasts during and after implantation (10). Also, it was observed that both proteins are distributed in the cytoplasm of cytotrophoblasts and cytoplasm and plasma membrane of the syncytiotrophoblasts (15). In contrast, uPA and tPA expression in rat embryos has occurred during their early embryonic development, while uPA was distributed in the cell cytoplasm, tPA was appeared only on cell surface and in the perivitelline space (1). Because PAs are implicated in early stages of development and embryo implantation, we expected that the expression of PAI-1 and 2 (inhibitors of PAs) could be suppressed, or very limited during embryogenesis. However, our data indicate that both proteins are strongly and entirely expressed in the embryos at the 2-cell $\sim$ the blastocyst stages, suggesting that PAI-1 and 2 proteins may not inhibit roles of PAs in oocyte meiotic maturation, ovulation, fertilization and embryo implantation. In fact, several studies showed that PAI-1 is a multi-functional protein that plays a role in physiological and pathological processes such as tissue remodeling, embryogenesis, regulating cell proliferation and migration, adhesion and tumor invasion, angiogenesis and metastasis $(3,19,20,28)$. Mashiko et al. (23) and Giacoia et al. $(12,13)$ suggested that PAI-1 inhibition promotes cell cycle arrest and apoptosis in ovarian and bladder cancer, and PAI-1 knockdown resulted in significant suppression of cell growth in cancer cells. The evidence suggests that PAI-1 may have some unique role associated with embryogenesis rather than inhibiting PAs.

It has been known that PAI-1 levels in the plasma gradually increased during normal pregnancy and reached maximum at 32-40 weeks of pregnancy, while PAI levels fall again 5-8 weeks after the birth in healthy pregnant women (14). PAI-1 may also play a role in remodeling maternal uterine spiral arteries (11). Hypoinvasion and unsuccessful placental vascular remodeling are related with intrauterine growth restriction, maternal and fetal death $(18,32)$. Depending on this information, previous studies demonstrated that any pathological disturbance in PAI-1 concentrations can cause pregnancy complications (27) and PAI-1 expression is increased in recurrent pregnancy losses, pre-eclampsia, intrauterine growth restriction and gestational diabetes mellitus (33). Intriguingly, Carmeliet et al. (6) indicated that PAI-1 deficient mice were viable and could generate morphologically normal offspring with normal litter sizes. PAI-2 exists in human plasma and its expression levels are increased during normal pregnancy, suggesting a possible requirement for PAI-2 during early development and/or placentation (4). However, Dougherty et al. (8) reported that PAI-2 is not required for normal murine development, survival and fertility. Our findings showed the localization of PAI-1 and 2, in cytoplasm and nucleus in all developmental stages, suggesting possible roles of these genes in preimplantation embryo development.

In this study our results indicated that, PAI-1 and PAI-2 are expressed in both cytoplasm and nucleus during all stages of preimplantation development in mice, suggesting that they may play roles in early stages of embryonic development. Especially expression of PAI-1 and PAI-2 in the trophectoderm supports the idea that these genes can be important for proper implantation and placentation. Further studies are required to fully understand the functions of PAI-1 and PAI-2 in embryogenesis.

\section{Acknowledgements}

This work was supported by research grants from Weinman Foundation Fund (PI-CJR), 5P30CA07178906071 (CJR Investigator) and 1 R01 CA198887 01A (CJR).

\section{Conflict of Interest}

The authors declared that there is no conflict of interest.

\section{References}

1. Aflalo ED, Sod-Moriah UA, Potashnik G, et al (2005): Expression of plasminogen activators in preimplantation rat embryos developed in vivo and in vitro. Reprod Biol Endocrinol, 3, 7.

2. Astedt B, Lindoff C, Lecander I (1998): Significance of the plasminogen activator inhibitor of placental type (PAI2) in pregnancy. Semin Thromb Hemost, 24, 431-435.

3. Balsara RD, Ploplis VA (2008): Plasminogen activator inhibitor-1: the double-edged sword in apoptosis. Thromb Haemost, 100, 1029-1036. 
4. Brenner B (2004): Haemostatic changes in pregnancy. Thromb Res, 114, 409-414.

5. Canipari R, Strickland S (1985): Plasminogen activator in the rat ovary. Production and gonadotropin regulation of the enzyme in granulosa and thecal cells. J Biol Chem, 260, 5121-5125.

6. Carmeliet P, Kieckens L, Schoonjans L, et al (1993): Plasminogen activator inhibitor-1 gene-deficient mice. I. Generation by homologous recombination and characterization. J Clin Invest, 92, 2746-2755.

7. Collen D (1980): On the regulation and control of fibrinolysis. Edward Kowalski Memorial Lecture. Thromb Haemost, 43, 77-89.

8. Dougherty KM, Pearson JM, Yang AY, et al (1999): The plasminogen activator inhibitor-2 gene is not required for normal murine development or survival. Proc Natl Acad Sci USA, 96, 686-691.

9. Fang H, Placencio VR, DeClerck YA (2012): Protumorigenic activity of plasminogen activator inhibitor1 through an antiapoptotic function. J Natl Cancer Inst, 104, 1470-1484.

10. Feinberg RF, Kao LC, Haimowitz JE, et al (1989): Plasminogen activator inhibitor types 1 and 2 in human trophoblasts. PAI-1 is an immunocytochemical marker of invading trophoblasts. Lab Investig J Tech Methods Pathol, 61, 20-26.

11. Feng Q, Liu Y, Liu K, et al (2000): Expression of urokinase, plasminogen activator inhibitors and urokinase receptor in pregnant rhesus monkey uterus during early placentation. Placenta, 21, 184-193.

12. Giacoia EG, Miyake M, Lawton A, et al (2014): PAI-1 leads to G1-phase cell-cycle progression through cyclin D3/cdk4/6 upregulation. Mol Cancer Res, 12, 322-334.

13. Giacoia EG, Miyake M, Goodison S, et al (2013): Targeting plasminogen activator inhibitor-1 inhibits angiogenesis and tumor growth in a human cancer xenograft model. Mol Cancer Ther, 12, 2697-2708.

14. Hellgren M (2003): Hemostasis during normal pregnancy and puerperium. Semin Thromb Hemost, 29, 125-130.

15. Hofmann GE, Glatstein I, Schatz F, Heller D, et al (1994): Immunohistochemical localization of urokinasetype plasminogen activator and the plasminogen activator inhibitors 1 and 2 in early human implantation sites. Am J Obstet Gynecol, 170, 671-676.

16. Huarte J, Belin D, Vassalli JD (1985): Plasminogen activator in mouse and rat oocytes: induction during meiotic maturation. Cell, 43, 551-558.

17. Huarte J, Vassalli, JD, Belin D, et al (1993): Involvement of the plasminogen activator/plasmin proteolytic cascade in fertilization. Dev Biol, 157, 539-46.

18. Kaufmann P, Black S, Huppertz B (2003): Endovascular trophoblast invasion: Implications for the pathogenesis of intrauterine growth retardation and preeclampsia. Biol Reprod, 69, 1-7.
19. Lee CC, Huang TS (2005): Plasminogen activator inhibitor-1: the expression, biological functionsand effects on tumorigenesis and tumor cell adhesion and migration. $\mathrm{J}$ Cancer Mol, 1, 25-36.

20. Lijnen HR (2005): Pleiotropic functions of plasminogen activator inhibitor- 1. J Thromb Haemost, 3, 35-45.

21. Liu YX (2004): Plasminogen activator/plasminogen activator inhibitors in ovarian physiology. Front Biosci, 9, 3356-3373.

22. Markiewski MM, Nilsson B, Ekdahl KN, et al (2007): Complement and coagulation: strangers or partners in crime? Trends Immunol, 28, 184-192.

23. Mashiko S, Kitatani K, Toyoshima M, et al (2015): Inhibition of plasminogen activator inhibitor-1 is a potential therapeutic strategy in ovarian cancer. Cancer Biol Ther, 16, 253-260.

24. Mehta BN, Nath N, Chimote N (2014): Periodicity in the levels of serum plasminogen activator inhibitor-1 is a robust prognostic factor for embryo implantation and clinical pregnancy in ongoing IVF cycles. J Hum Reprod Sci, 7, 198-205.

25. Mutluay D (2016): Distribution of primitive endoderm and epiblast lineage specific factors in late stage blastocysts. Slov Vet Res, 53, 211-217.

26. Mutluay D, Oner H (2017) The Abelson tyrosine kinase (cAbl) localization in preimplantation mouse development. Rom J Morphol Embryol, 58, 1385-1391.

27. Pihusch M, Pihusch V, Holler E (2005): Plasminogen activator inhibitor-1: A review. J Lab Med, 29, 403-411.

28. Placencio VR, DeClerck YA (2015): Plasminogen Activator Inhibitor-1 in Cancer: Rationale and Insight for Future Therapeutic Testing. Cancer Res, 75, 2969-2974.

29. Pyke C, Kristensen P, Ralfkiaer E, Eriksen J, Danø K (1991): The plasminogen activation system in human colon cancer: messenger RNA for the inhibitor PAI-1 is located in endothelial cells in the tumor stroma. Cancer Res, 51, 40674071.

30. Saksela, O, Rifkin DB (1988): Cell-associated plasminogen activation: Regulation and physiological functions. Annu Rev Cell Biol, 4, 93-126.

31. Sappino AP, Huarte J, Belin D, et al (1989): Plasminogen activators in tissue remodeling and invasion: $m R N A$ localization in mouse ovaries and implanting embryos. $\mathrm{J}$ Cell Biol, 109, 2471-2479.

32. Soares MJ, Chakraborty D, Kubota K, et al (2014): Adaptive mechanisms controlling uterine spiral artery remodeling during the establishment of pregnancy. Int $\mathbf{J}$ Dev Biol, 58, 247-259.

33. Ye Y, Vattai A, Zhang X, et al (2017): Role of plasminogen activator inhibitor type 1 in pathologies of female reproductive diseases. Int J Mol Sci, 18, pii: E1651.

34. Zhang X, Rutledge J, Khamsi F, et al (1992): Release of tissue-type plasminogen activator by activated rat eggs and its possible role in the zona reaction. Mol Reprod Dev, 32, 28-32. 